\title{
Continuity and Change in the Luba Christian Movement, Katanga,
}

\author{
Belgian Congo c.1915-50 \\ By DAVID MAXWELL \\ Emmanuel College, Cambridge \\ E-maildjm223@cam.ac.uk
}

In the wake of the First World War a movement of popular Christianity took force amongst the Luba speaking peoples of southeast Katanga, Belgian Congo. The movement shared many characteristics with others that traversed Africa in the same era described by Adrian Hastings in his magisterial The Church Africa. ${ }^{1}$ Katangese popular Christianity bore particular resemblance to the better known Congolese movement which occurred amongst the Bakongo in the 1920s in which the prophet and former Baptist catechist, Simon Kimbangu, was the most prominent of a number of actors. ${ }^{2}$ At first glance Luba popular Christianity represented a seismic shift in $\mathrm{CAM}=$ Central African Missions (fomerly Congo Evangelisic Mission), Preston.

$C E M R=$ Congo Evangelistic Missionary Report

$\mathrm{CSSp}=$ Archives de la Congrégation des Pères du Saint Esprit, Paris, France

$R W=$ Report of Work

SADU $=$ Springer Archives, Drew University, USA

I am grateful Joel Cabrita, John Lonsdale and Emma Wild-Wood for comments on earlier drafts of this paper.

This research was supported by the Nuffield Foundation and the Economic and Social Research Council: [RES-00023-1535].

${ }^{1}$ A. Hastings, The Church in Africa, 1450 - 1950, Oxford 1994, 454-6

${ }^{2}$ There were earlier smaller waves of conversion amongst the Bakongo: W. MacGaffey, Modern Congo prophets, Bloomington, 1983; J-L Vellut, Simon Kimbangu. 1921: de la prédication à la déportation. Les Sources. Vol. 1. Fonds missionnaires protestants, Brussels 2005; J. Stengers and J. 
religious belief and practice. Conversion was marked by stronger recognition of the unity and sovereignty of God, some personal attachment to Christ, and a belief in the value of baptism as a sign of these changes. Vigorous hymn singing (often strongly Christocentric in content) and the public reading and discussion of the scriptures were the prominent public features of this new mass Christianity. It was also marked by the keeping of a Sabbath, usually Sunday, and by certain new moral strictures such as the prohibition of human sacrifice. In addition, the movement was self-consciously modernising, displaying a strong desire for bush schools and literacy, and aggressively rejecting traditional religious objects, which were often burnt in huge public bonfires. Nevertheless, the resulting network of village Christianities that traversed the south east Katanga retained a good deal of former cosmological belief, especially ideas relating to personal security, social obligation and an abundant life. The Luba Christian movement was African-led, whereby Catholic catechists and Protestant evangelists along with more autonomous groups of African Christians pushed the Christian frontier well beyond mission stations. Thus Christianity spread much like other African religious movements before it, animated by rumour of prophecy and healing, and by the appropriation of those Christian rites and symbols that had most traction in local society. Indeed, the enthusiastic abandonment of charms and medicines that accompanied Christian proclamation gave the movement the appearance of a witchcraft eradication cult, used by young men to subvert the authority of chiefs and diviners. Nevertheless it was a movement in which missionaries played a significant part, providing protection and resources along with new ideas, symbols and practices, even if such provision gave them the appearance of

Vansina, 'King Leopold's Congo, 1886-1908' in R. Oliver and N. Sanderson (eds), The Cambridge History of Africa, Vol.6. From 1870-1905, Cambridge 1985, 347-8. 
wonder working prophets barely distinguishable from African prophetic figures of old. ${ }^{3}$

The notion of religious conversion continues to provoke heated debate amongst historians and social anthropologists. In an influential essay on the anthropology of Christianity, Joel Robbins observed that most anthropological theories emphasized 'cultural continuity as opposed to discontinuity and change' arguing that 'this emphasis becomes problematic where Christianity is concerned, because many kinds of Christianity stress radical change and expect it to occur. Confronted by people claiming that radical Christian change has occurred in their lives, anthropologists become suspicious and often explain away the Christian elements of their cultures'. Robbins' argument is profoundly shaped by his ethnographic research amongst the Urapmin of Melanesia published in his monograph Becoming Sinners. ${ }^{5}$ At the time of Robbins' research the Urapmin were experiencing evangelical revival for the first time. New adherents placed great stress upon public confession, and the search for purity and sincerity. But context is important. The element of discontinuity, a faith worth martyrdom, is often necessary for first generation converts. Those renouncing a system of belief and practice that has dominated their life, their worldview and public conventions to adopt another religion, often do so with a rigour that may appear excessive to the outsider. Where scholars working on African Christianity

\footnotetext{
${ }^{3}$ T.O. Ranger, 'Religious movements and politics in sub-Saharan Africa', African Studies Review 29, 2 (1986) 33-4.

${ }^{4}$ J. Robbins, 'Continuity thinking and the problem of Christian culture', Current Anthropology, 48, 1 (2007), 5 .

${ }^{5}$ J. Robbins, Becoming Sinners: Christianity and moral torment in a Papua New Guinea society, Berkeley, 2004.
} 
have been able to reconstruct religious change over several generations, complex patterns appear. While radical discontinuities do occur, the cleavages appear less profound when located within pre-conversion dynamics of cyclical societal cleansing. Moreover, what was once cast aside as demonic is sometimes reintroduced as heritage or nostalgia. In his study of a Christian movement in Botswana, Richard Werbner has shown how the second generation of Christianised children who neither experienced the rupture of conversion nor the old life as a social and spiritual entity have sought a self-conscious rapprochement with their parents' former culture through acts of reprise within Christianity. ${ }^{6}$ Thus, it is important to trace the dialectic of conversion over generations, locating movements of individual and collective rupture within the fine grain of religious change, asking precisely when and why different social categories responded to new religious ideas and practices, and what forms their responses took. This historical approach is particularly suited to the Congo Region where the missionary encounter began in the late fifteenth century, and where scholars have been able to discern long-term patterns of religious change. It is only when viewed in the longue durée as well as its immediate context that the dynamics of the Luba Christian movement become fully apparent.

Returning to the Luba case, although there were differences between Catholic and Protestant religious expressions there were enough commonalities for them to constitute a single movement. There was a synchronised response to Christianity by children and young men who acted as agents of disenchantment, actively breaking secrets and objects associated with traditional religious practice. Their proselytising

\footnotetext{
${ }^{6}$ R. Werbner, Holy hustlers, schism and prophecy. Apostolic Reformation in Botswana, Berkeley, 2011.
} 
zeal was matched by a desire for literacy mediated by the scriptures, religious primers and the catechism. The most significant Protestant movement working amongst the Luba was the Congo Evangelistic Mission (CEM), a Pentecostal, faith-mission, founded by William F.P. Burton and James Salter in 1915. The Brethren commenced work in Mulongo in 1911 founding several stations on the east bank of the Congo Lualaba River, and the American derived Methodist Episcopal Church established one station in Kabongo in 1917. The Holy Ghost Fathers, better known as the Spiritans, who commenced at Kongolo in 1909 and reached Malemba Nkulu in 1912, pioneered the major Catholic work. The Scheutists and the Franciscans subsequently founded other Catholic stations. But it was the CEM that occupied most of the Luba territory. By 1932 some 50 white missionaries and their Congolese allies had established no less than a dozen stations, 300 schools and 3000 assemblies reaching over 1000 villages in a region of 80,000 square miles. $^{7}$ Analysis will focus mainly on the encounter between the CEM and the Luba but will draw upon data from other missionary movements for comparative purposes.

\section{The End of Tradition and the Beginning of Luba Christianity}

In Paths in the Rain Forest Jan Vansina argues that in the 40 years of colonial conquest preceding the First World War, the millennia-long equatorial 'tradition' of institutions and modes of thought was shattered: 'A combination of war, destruction by fire, disease and hunger finally succeeded in breaking overt African resistance by

\footnotetext{
${ }^{7}$ D. Garrard, 'History of the Zaire Evangelistic Mission/ Communauté Pentecôtiste au Zaire 1915-82', unpubl. PhD diss. Aberdeen, 1983.
} 
1920, at a cost of an estimated half the total population of the area. ${ }^{8}$ Vansina's argument also holds for the adjacent Savannah area where the Luba resided. If there was to be an era when crisis demanded radical social and religious change then the 'trauma of colonial penetration and its aftermath' marked such a time. ${ }^{9}$ The forced recruitment of porters and workers, the requisitioning of crops, the influenza pandemic of 1918-20, and the post-war price rises and shortages combined to take their toll. ${ }^{10}$ These crises followed an earlier series of shocks dating from 1870s when the Luba polity was undermined and overwhelmed by a combination of internal and external forces: succession disputes within the royal family; Swahili and AfroPortuguese slavers in alliance with the Yeke; and the Batetela wars.

Missionary organisations present in the Congo in the late nineteenth century prior to the consolidation of Belgian colonialism made little headway with conversion. The Scheut Fathers in Kasai did make some adherents but many of these were deathbed conversions. Elsewhere, African leaders sought out missionaries for knowledge of how to manage the growing number of whites entering their territories, or for help to procure arms and trade in order to get ahead of their enemies, but were often unwilling to accept the changes in lifestyle and government that missionaries demanded of them. Conversions in significant numbers usually commenced only with the breakup of the African polities under the impact of Belgian colonial occupation. The classic case was the Brethren mission at Luanza where its founder,

\footnotetext{
${ }^{8} \mathrm{~J}$. Vansina, Paths in the rainforests. Towards a history of political tradition on Equatorial Africa, London, 1990, 239.

${ }^{9}$ B. Jewsiewicki, "Belgian Africa" in A. Roberts (ed.), The Cambridge History of Africa, Vol. 7. From 1905 to 1940 . Cambridge1986, 470.

${ }^{10}$ Vellut, Kimbangu, ix-x.
} 
Dan Crawford became Konga Bantu, the gatherer of people, a white Christian chief, whose station provided security for by those fleeing the break-up of the Yeke kingdom in $1891 .{ }^{11}$ Other pioneer missionaries such as Burton and Salter, working at the CEM's first station at Mwanza, were similarly viewed as new patrons in the vacuum of political authority that accompanied the colonial occupation. Sporadic violence within local chiefdoms and between Africans and the colonial state continued into the late 1910 s and mission stations were often sites of refuge. Indeed, the protection of those without kin was central to Christianisation during the early stage of the encounter.

Like many missionary pioneers, Burton and Salter were initially overwhelmed by their circumstances. Along with the challenges of securing sustenance and shelter and surviving periodic bouts disease, they barely had time for evangelism and when they did, there was the added challenge of proselytising in Kiluba. ${ }^{12}$ Although he subsequently became an excellent linguist, Burton's early sermons were 'weak attempts' deploying 'a few hundred faltering and poorly understood native words'. ${ }^{13}$ To begin with both Burton and Salter relied upon African Christian agents who would 'frequently translate [their] blunderings into understandable Kiluba'. ${ }^{14}$ The dynamics

\footnotetext{
${ }^{11}$ R. Rothberg, 'Plymouth Brethren and the occupation of Katanga, 1886-1907', Journal of African History, 5, 2 (1964), 285-97. See also Jan Vansina, Being colonised. The Kuba experience in rural Congo, 1880-1960, Wisconsin, 2010, 91, 279.

${ }^{12}$ W.F.P. Burton, $R W, 21$ July (1918). See also D. Maxwell 'The Missionary Home as a site for Mission: Perspectives from Belgian Congo' in John Doran Charlotte Methuen and Alexandra Walsham (eds), Religion and the Household, (Studies in Church History 50, 2014) 428-55.

${ }^{13}$ W.F. P. Burton, When God Changes a Man, London 1929, 47.

${ }^{14}$ J. Salter, Abraham: Our First Convert. London 1936, 11.
} 
of the ensuing Christian movement can be reconstructed from missionary publications and corroborated via African personal reminiscences. The early career of the CEM's first convert, fittingly named Abraham, is instructive. Missionary accounts of his conversion emphasize the immense conceptual leap he made in response Burton and Salters' preaching in broken Kiluba, which was accompanied by gesticulations. ${ }^{15}$ After a short period of formation in the missionaries' home, he was quickly given responsibility for teaching other evangelists. According to Burton, Abraham 'would take a simple gospel theme, teach it to the young believers, and then send them back out to preach it in half a dozen villages, coming back later to get another sermon and so forth like that'. ${ }^{16}$ Hence, there were two iterations from the initial missionary message before it reached the village, providing much room for local appropriation. Moreover, the evangelists 'were pastors of their own assemblies' with power to discipline and authority to decide when a convert was fit for baptism. ${ }^{17}$ Propelled by local agency the movement expanded rapidly and in 1918 Burton estimated that just six evangelists could reach 6,300 people in a week. ${ }^{18}$ Missionaries asserted the right to oversight of local assemblies by 'blessing or ratifying' conversions made by evangelists on outstations but for much of 1920s 'each individual assembly could only hope for a visit [from a missionary] ... once in several months' ${ }^{19}$ In effect processes

\footnotetext{
${ }^{15}$ W.F.P. Burton, God Working With Them: Being Eighteen Years of Congo Evangelistic Mission History, London, 1933, 34.

${ }^{16}$ Burton, God Working, 37. Interview conducted by David Maxwell with Ngoy Kabuya, Ruashi, Democratic Republic of Congo, 13 May 2007.

${ }^{17}$ Burton, God Working, 99.

${ }^{18}$ M. Moorhead, Missionary pioneering in Congo forests, Preston 1922, 103-4.

${ }^{19}$ W.F.P. Burton, Honey Bee. Life story of a Congo evangelist, Johannesburg c.1959, 48.
} 
of linguistic and cultural translation were turned over to those Lamin Sanneh calls 'indigenous cultural experts'. ${ }^{20}$

The parameters of the Luba Christian movement were set by a variety of actors. African catechists and evangelists from Nyasaland and the Rhodesias accompanied the Protestant missionaries movements entering Katanga in the 1910s. Christians from the West of the colony, which had been missionized earlier, aided Catholic missionaries. These African agents provided crucial services as translators and intermediaries in the initial stages of the encounter. Other social groups particularly responsive to Christianity quickly replaced them. J.D.Y. Peel explained the process most effectively with his model of 'opportunity costs' used to account for conversion amongst the Yoruba of West Africa. Initial converts were often those on the social periphery such as outsiders and ex-slaves. These groups were more religiously biddable than natives - - they had lost the spiritual support of home communities and, in the absence of relatives, were more at liberty to make revolutionary religious choices. While the wider horizons that travel, enslavement and relocation engendered made Christianity more metaphorically appealing. ${ }^{21}$

At Kindu and then Kongolo the Spiritans encountered ready-made Christian communities of Ouvriers and Licencies, current and former workers who had been employed in railway construction in other parts of the colony and beyond -- Bas Congo, Bangala, Kasay, Bakusu, Bangubangu [sic] - and many had already chosen

\footnotetext{
${ }^{20}$ L. Sanneh, Translating the Message. The Missionary Impact on Culture, New York 1989, 5.

${ }^{21}$ J.D.Y. Peel, Religious encounter in the making of the Yoruba, Bloomington 2000, 233-47.
} 
Christian baptism. ${ }^{22}$ Considering themselves more civilised than their pagan neighbours, they had no wish to live under the authority of pagan chiefs and chose to relocate onto mission stations or found their own villages in the vicinity. A returnee movement of ex-slaves aided the three Protestant missions in Katanga. These former slaves had been taken into captivity by Ovimbundu slavers during the break-up of the Luba polity c. 1870-1900. While labouring in plantations in Bié Angola the captives had been Christianised at mission stations of the Plymouth Brethren, the American Board of Commissioners for Foreign Missions and the Canadian Congregationalists in Bié, Angola and once liberated in 1910 had returned to Belgian Congo, considering themselves as missionaries. Attaching themselves to mission stations for patronage and the safety of fictive kin, they pushed the Christian frontier ahead of the missionary frontier through evangelising local communities, bringing back enquirers for teaching and baptism and eventually founding their own Christian villages. They acted as representatives of a Christian modernity via the introduction of literacy, new styles of architecture and construction, new types of dress, cultivation and animal husbandry. ${ }^{23}$ Their impact was immense. Ex-slaves helped Burton and Salter pioneer Mwanza and many of its sub-stations. They collaborated with the American Methodist John McKendree Springer in the founding of the Kabongo station, and kept alive the Brethren Mission in Mulongo in the absence of its German missionary who was interned during the Great War. ${ }^{24}$

\footnotetext{
${ }^{22}$ CSSp, Bulletin de la Congrégation, Tome XV 1915-17, Préfecture du Katanga Nord (1913-16).

${ }^{23}$ D. Maxwell, 'Freed slaves, missionaries and respectability: The expansion of the Christian frontier from Angola to Belgian Congo', Journal of African History, 54, 1 (2013), 79-102.

${ }^{24}$ Interview conducted by David Maxwell and David Garrard with Mwila Kilolo, Ruashi, Democratic Republic of Congo, 4 September 2015.
} 
The first major social category amongst the Luba to adopt Christianity was young men who bore the brunt of gerontocratic power and were least locked into existing religious institutions prior to their first marriage. Burton observed there was 'a very rigid order of preference in the social structure of the Luba ... which often embitters the whole lives of natives'. ${ }^{25}$ Young men were at the bottom of that hierarchy, excluded from positions of influence in village politics and traditional religious associations. Young men became the zealous foot soldiers of the Luba conversion movement. Their aggressive evangelism was complemented by the work of disenchantment whereby they mounted extirpation campaigns that destroyed indigenous artefacts and sites associated with divination and ancestor religion, which legitimated the dominance of elder male elites. Like Christianised railway workers and the returnees they also separated themselves from traditional leadership forming their own suburbs in villages and such was effect of this relocation that in 1926 territorial administrators complained that conversion was undermining indirect rule through chiefs. $^{26}$

Spiritan missionaries were more pessimistic than Protestants about their ability to turn the Congolese into proper Christians. They viewed those living in communities of labourers as prone to cling to sacrifices, superstitions, ritual dances and polygamy, while those Catholics who worked as servants for whites were viewed as corrupted by their employers' immoral ways. It was best to start afresh and form authentic

\footnotetext{
${ }^{25}$ W.F.P. Burton, Luba religion and magic in custom and belief, Tervuren, 1961, 55-6.

${ }^{26}$ Burton, Honey Bee, 66, 72.
} 
Catholics from childhood. ${ }^{27}$ Indeed children flocked to the Catholic schools, keen to learn the catechism and wear distinctive new uniforms. Young people left their villages to reside at the Catholic mission station at Lake Kisale for instruction with 'une étonnante rapidité' on its foundation in 1912. Some Catholic youth became loyal allies of missionaries, happy to break secrets and reveal where the sick lay hidden so that priests could administer prayer and last rites. ${ }^{28}$ While Catholicism placed more emphasis on the mediation of the priest than the scriptures, rudimentary schooling and literacy were nevertheless a priority for Spiritans who opened a network of village schools across Katanga, teaching the catechism and selecting the best students as catechists and later for Holy Orders. Although their own rich iconography made Catholic missionaries far more ambivalent about the place of material representations of the divine, they still encouraged the destruction of so-called 'fetishes' and abolition of 'sacrifices' as the marks of a false religion. Indeed there was a Congolese Catholic tradition stretching back to the late fifteenth century, which condemned the traditional healer - Nganga -- for his supposed diabolic and superstitious practices. ${ }^{29}$

The axiom that the twentieth century African Christian movement was a woman's movement did not apply to the Luba context. ${ }^{30}$ Luba women initially proved more

\footnotetext{
${ }^{27}$ CSSp, Cote 7j1.1a2 Congo Belges/Projets Divers / Historique, 1841-1919, Conrad, P. “Quelques Considérations sur nos chrétiens" 1 Jan. 1917.

${ }^{28}$ Le Messenger du Saint Esprit, Mai 1913.

${ }^{29}$ J. Thornton, "The development of an African Catholic Church in the Kingdom of the Kongo, 14911750”, Journal of African History, 25 (1984),158.

${ }^{30}$ B. Sundkler, 'African Church history in a new key', in K. Holst-Peterson (ed.) Religion Development and African Identity. Uppsala,1987, 83. This was often the pattern in Southern Africa but it also did not apply to the Yoruba see Peel, Religious Encounter, 234-40
} 
resistant to Christianity than young men. Luba culture ascribed women a status complementary with men whereby they reproduced royal ideology and practice. Through coiffures, cicatrisation, and adornment, their bodies became 'receptacles of spiritual energy and beholders of political secrets'. ${ }^{31}$ And missionary strictures about Christian marriage seemed to limit the options of older women to bear and successfully rear children. Young girls were often shielded from missionary proselytism in order to safeguard their value in arranged marriages. ${ }^{32}$ Once again the first female converts were marginal types, often 'runaways' - women fleeing domestic slavery or abusive relationships. ${ }^{33}$ Burton's wife, Hettie, founded a women's refuge, which beside those in flight, attracted abandoned infants and widows who lacked the security of living children. ${ }^{34}$ Young girls intended for polygamous marriages were redeemed by the Spiritans at the cost of 200 francs, paid in cash or cloth, and sent to school. ${ }^{35}$ However, by the late 1920 s the desire to maximise the chances of biological reproduction drew many women to Christianity as they grasped the benefits of missionary medicine and midwifery. Subsequently, the prayer band and the fellowship meeting offered a vital source of solidarity for women otherwise divided by exogamy, polygamy, and fear of witchcraft accusation.

\footnotetext{
${ }^{31}$ M. Nooter Roberts, A. \& Roberts (eds), Memory. Luba Art and the Making of History, New York 1996 , ch 3 .

${ }^{32}$ CSSp. Annales Apostolique, Nov.- Dec. 1925,169-70

${ }^{33}$ M. Wright, Strategies of slaves and women. Life stories from East/ Central Africa, London, 1993.

${ }^{34}$ H. Burton, My black daughters, London, 1949.

${ }^{35}$ CSSp. Annales Apostolique, Nov- Dec 1925, 169-70
} 


\section{Literacy and the new Christian subject}

The conversion of young men and subsequently women to Christianity represented a series of disjunctions with Luba traditional religion and culture. Conversions entailed real moments of choice, cost and commitment. Converts ended ritual sacrifice and publicly burnt their witchcraft and sacred objects at 'bonfire meetings'. Mothers removed protective charms from the legs and necks of their children, choosing to rely on the Holy Spirit for protection. The sick visited Church elders for prayer and the laying on of hands rather than pay for the services of a traditional healer. Adult baptism symbolised the clash of old and new in stark terms as new believers publicly renounced the authority of chiefs. Such actions often met with a violent response from disapproving parents and husbands. ${ }^{36}$ Some enquirers walked for days to learn more of the new Christian ideas that were being discussed in their villages, often foregoing planting and harvesting to ensure a good period of instruction. Transcriptions of African sermons in the bi-monthly periodical CEMR and missionary hagiographies reveal how converts were captured by the new revolutionary idea of personal responsibility. ${ }^{37}$ It was their own actions rather than the malevolent intentions of their kin, neighbours and spirit world, which determined their fate. Such a notion was underpinned by ideas of judgement, heaven and hell, which although existed in preChristian Luba culture, were sharpened and popularised by the preaching activities of missionaries and their African evangelists and catechists who preached them with a

\footnotetext{
${ }^{36}$ Burton, When God Changes a Village, 32-55. K. Fields, 'Charismatic religion as popular protest. The ordinary and the extraordinary in social movements', Theory and Society, 11, 3 (1982), 346.

${ }^{37}$ Burton, Honey Bee, 25.
} 
millennial urgency. ${ }^{38}$ The growing appeal of ideas about an afterlife was doubtless a response to the omnipresence of death in early colonial Belgian Congo.

Christianity created a new kind of individualised subjectivity beyond kinship, the membership of associations and cults, and the patronage of big men. Henceforth the new believer, called by God, took on a new fixed baptismal name and joined a new Christian community. As Karen Fields has observed for the comparable case of the Watch Tower Movement in colonial Zambia, the language of conversion - 'coming forward', 'setting yourself apart' provided a new cohort of young men with 'legitimate grounds for denying the formerly legitimate obligations' of their elders. ${ }^{39}$ These new subjectivities were also a response to the demands of the new colonial political economy, which required Christian missions to produce a disciplined worker with a broader commitment to monogamy, the nuclear family sobriety and hygiene in order to secure a reservoir of labour. ${ }^{40}$

Literacy proved to be a key means of forging new identities and recasting social relations in favour of youth and new social classes. The act of reading sharpened the growing sense of selfhood amongst young converts, particularly as Protestantism demanded converts who approached God via the scriptures rather than through spirit possession. ${ }^{41}$ At the same time it enabled a new generation of mission-schooled elites,

\footnotetext{
${ }^{38}$ Salter, Abraham, 32-5.

${ }^{39}$ K. Fields, Revival and rebellion in colonial Central Africa, Princeton, 1985, 41, 46.

${ }^{40}$ J. Fabian, 'The colonization of African languages', Canadian Journal of African Studies, 17, (1983), 178.

${ }^{41}$ B. Meyer, 'Religious revelation, secrecy and the limits of visual representation', Anthropological Theory, 6, 4, (2006), 438.
} 
teachers, evangelists, clerks and labour migrants to challenge their elders by drawing authority not from legal utterances or ability to organise domestic production but via mastery of the printed word that allowed them to comprehend the practices of an alien colonial state. Literacy, as Lonsdale observes, had 'a wider convening power than elders' speech' allowing 'Africans to conceive of larger moral communities' ${ }^{42}$

All of the missionary organisations working in South East Congo reported a vigorous grassroots response to literacy. Soon numerous schools opened in mining compounds ${ }^{43}$ and literacy was quickly recognised as a source of social mobility, a means of understanding the 'symbols and codes of whites'. ${ }^{44}$ In 1915, American Methodist, John McKendree Springer, wrote: 'Everywhere constantly the cry was BOOKS, books, books! ${ }^{45}$ An ecumenism of Protestant publishing evolved to meet this demand. The CEM distributed Brethren Luba New Testament published in 1920 while the American Methodists made use of CEM primer Nkindi [Proverbs] published in 1921. By 1925 the initial print run of 2000 primers needed to be supplemented with 6000 new copies. ${ }^{46}$ Around 1925 the CEM began to use the Brethren primer Kibelo - [The Doorkeeper ${ }^{47}$

\footnotetext{
${ }^{42}$ J. Lonsdale, 'Unhelpful pasts and a provisional present' in E. Hunter (ed.), Citizenship, Belonging and Political Community in Africa: Dialogues Between Past and Present, Athens, 2016, 26-7.

${ }^{43}$ SADU, First Meeting, Methodist Episcopal Church, Kambove, 1915, Springer Report, 1

${ }^{44}$ For a similar response to literacy amongst the Thonga of Southern Africa see: P. Harries, Butterflies and barbarians. Swiss missions and systems of knowledge in South-East Africa, Oxford, 2007, ch 7.

${ }^{45}$ SADU, First Meeting, 15.

${ }^{46}$ CAM, file, Burton to Salter, 11 Nov 1925.

${ }^{47}$ Garenganze Evangelical Mission, Kibelo.
} 
Recent social history and anthropology of Christianity has stressed the variety of nonliterary uses of the Bible and Christian religious literature from cigarette and toilet paper, to the sacred substances used in charms and amulets for healing and protection. ${ }^{48}$ Such insights do help explain the broad appeal of books amongst the Luba but there was a great interest in the import of the Christian message itself. James Salter's description of the reception of Luba Gospels and Psalms in 1921 captures the complexity of the popular response. All those given a copy of the scriptures wanted their names written inside. Salter also noted that each church member wrapped their text in paper to keep it clean but he was doubtless unaware of the Congolese practice of covering sacred objects to enhance their talismanic quality. ${ }^{49}$ The following Sunday the mission church service had record attendance and was extraordinarily long as all became 'little preachers'. Salter observed: 'Really there was nothing new; we had been telling them the same things for years, but now they had found them for themselves and that made them all alive... ${ }^{50}$

\section{Song, Proverb and Performance}

Though the word on paper became a new arbiter in disputes with elders its effect was gradual. The Luba New Testament was read aloud to Christian communities but only one in five converts could read it themselves by $1930 .^{51}$ Luba society was paraliterate one in which different forms of authority clashed and where oral genre remained efficacious. In 1917 CEM missionaries reported that the Luba 'never tire of song' and

\footnotetext{
${ }^{48}$ Harries; Butterflies, ch 7; J. Cabrita, Text and Authority in the South African Nazaretha Church, Cambridge, 2014, 96, 136, 213.

${ }^{49}$ Nooter Roberts and Roberts, Memory, 57, 66.

${ }^{50}$ Salter, Abraham, 27.

${ }^{51}$ CAM, Burton to Salter, 8 May 1930.
} 
it was this medium that first communicated Christian ideas. ${ }^{52}$ Prior to the publication of the vernacular New Testament, evangelists learnt hymns alongside the scriptures, in particular translations of evangelical classics by Moody and Sankey and more recent productions from the revival campaigns of Torrey and Alexander. In 1921 while itinerating in the USA, Burton adapted the Black-American spiritual, 'Way down the River' as 'Way down the Congo River'. This adaptation proved so popular that American Methodists borrowed it. ${ }^{53}$ A Luba rendition of American Baptist classic 'Up from the grave he arose' also proved popular. ${ }^{54}$ The Luba added their harmonies and sung these songs with great gusto at services, especially to accompany the destruction of hitherto sacred objects at bonfire meetings. Porters and roving evangelists sung to maintain their spirits and ward off evil thus carrying the Christian message across the Savannah.

As in many pre-literate or para-literate worlds, Luba words themselves had agency. Curses, spells, praise poetry, and oratory all influenced the capacity of a person to act in the world. A curse was believed to be potent enough to cause infertility, the death of an animal or the failure of a hunt, while a blessing from a diviner could help someone get ahead when dealing with authority. ${ }^{55}$ The Christian scriptures armed evangelists with a battery of admonitions, divine judgements and the occasional blessing with which to do battle with traditional religious leaders. Abraham, the CEM's first convert was renowned for 'preaching with violence', while one of one of

\footnotetext{
${ }^{52}$ W.F.P. Burton, $R W, 11$ (1917), 6

${ }^{53}$ SADU, file, 1001-7-7:06, Congo Evangelistic Mission, Burton to Springer, 8 May 1943.

${ }^{54}$ Burton, $R W, 11$ (1917), 6

${ }^{55}$ Burton, Luba religion, 88, 106-09.
} 
the movement's most prolific evangelists Mudishi engaged in extended verbal duels with his opponents. ${ }^{56}$ The latter, a former hunter, never learnt to read but memorised vast portions of scripture, which he used with great effect. ${ }^{57}$

The power of words was inseparable from political authority. For chiefs the legitimacy of a political claim in the absence of written documents rested largely on an eloquent case made to subjects. Missionaries often found themselves caught up in sophisticated debates about religion with elders who possessed extraordinary rhetorical skills, particularly their use of proverbs. CEM missionary Harold Womersley observed: 'To preach an understandable sermon one needs to leaven it with a few telling proverbs. The right proverb immediately catches the attention of the hearers' ${ }^{58}$ In his desire to reach traditional leaders Burton devoted much time and energy to comprehending Luba proverbial wisdom. His conversations with elders recounted in the CEMR, and later Congo Sketches (1950), were extended dialogues involving proverb and scripture. ${ }^{59}$ He quickly realised that the best means of making Christianity intelligible or plausible was to draw out its connections with pre-existing religious traditions. Indeed, this was the key to the widely disseminated Luba language primer, Nkindi [Proverbs]. Its 59 lessons each consisted of a proverb amplified by a verse of scripture followed by a Christian gloss. A compendium of folklore and fables, it appeared at first glance to depict Christianity as the culmination

\footnotetext{
${ }^{56}$ Interview, Ngoy Kabuya.

${ }^{57}$ Burton, Mudishi. On Christian blessings see Burton, When God changes a Village, 56.

${ }^{58}$ H. Womersely, Legends and History of the Baluba. Los Angeles 1984, xv

${ }^{59}$ W. F. P. Burton, Congo Sketches, London, 1950, 103-4.
} 
of Luba tradition. But as well as asserting continuities with what had gone before the primer also sought to cleanse and transform Luba culture in the process.

Nkindi asserted continuities in Luba names and attributes for God: Leza Waba (God who shares); Shakapanga (the Father of Creation), Kungwabeze (The Waiting one); Vidye Mukulu (the Eternal Spirit); Bundangulu (The heaper up of Hills); Leza Malangu (the God of Resurrections). In addition God became 'the Chief of chiefs', and Jesus the alternative chief. Nevertheless the text was highly selective in its rendition of Luba culture reducing it to the pristine rural world of the village even though the Luba were actively transforming themselves through wage labour and migration to mines and cities. Nkindi emphasised nature-lore, and bush-craft, particularly, hunting, and in the process previously morally neutral wild-beasts were transformed into Satan's accomplishes. In a similar manner, the entire Luba pantheon, whether good or bad in pre-existing cosmological terms, was collapsed into the domain of the diabolical. And sexually explicit proverbs were, of course, censored. The primer's format of dialogue between proverb and scripture mirrored that of African sermons, reproduced verbatim in missionary propaganda to illustrate the redeeming power of the word. It is difficult to discern which came first, but it is clear that young male evangelists had a strong hand in the writing of the primer: 'The messages of the Lord point you to the way of life, the way to heaven. Don't refuse to hear even if it's from a young person. The messenger may be young but his message is very big' ${ }^{60}$ More significant still were the recasting of gender relations. Not only were the lessons unrelentingly masculine in content but they also omitted to mention the range of traditional activities in which women participated such as craft, politics

\footnotetext{
${ }^{60}$ Congo Evangelistic Mission, Nkindi, Preston, 1921, lesson 25.
} 
and possession cults, thereby restricting them to a narrow domestic sphere. Women were also rendered objects of the male gaze -'other men's wives' - in lessons about the dangers of temptation. ${ }^{61}$ By reducing to simple textual form, rich oral traditions that could take an hour to recite and which could vary according to time, region and orator, the primers enabled literate Christian young men to become cultural experts themselves. $^{62}$

Lastly, there were profound ruptures in Luba temporalities. A key concept in local cosmology was the idea of rebirth, a cyclical conception of time most manifest in the belief that children were the reincarnations of their ancestors and that dead chiefs continued to intervene in the world through possession of human hosts. ${ }^{63}$ Christian temporality represented a significant epistemological shift. Ideas of the second coming and judgement were accompanied by an inherent teleology while the content of the biblical message contained explicit notions of cumulative moral development and of linear history. Moreover, Christian notions of modesty had a two-fold effect. Female converts rejected cicatarisation and elaborate coiffures, choosing to cover their bodies which had hitherto been inscribed as mnemonic texts about royal power, thus undermining the indigenous means of the remembering the past and once again shifting gender relations in favour of men. ${ }^{64}$

\footnotetext{
${ }^{61}$ Nkindi, lessons 38, 43, 55.

${ }^{62}$ W.F.P. Burton, 'Kanya Oral Literature in Lubaland', African Studies Review 2 (1943): 93-96

${ }^{63}$ W.H. Hall, 'The Kifikwa', CEMR, 42, (1933) 677-78; Burton, Luba religion, 25, 56, 79-80.

${ }^{64}$ H. Burton, Black Daughters, 62.
} 


\section{The Search for the Good Life}

Writing in 1913, Father Conrad, Superior of the Spiritan Mission, Nkulu, observed with profound ethnographic insight, the centrality of the good-life in Luba religion and culture. He found no atheism but instead a 'king' who offered up public prayers for peace, health and fertility to a creator god. ${ }^{65}$ In their classic article 'Religious Movements in Central Africa' De Creamer, Fox and Vansina identify this pursuit of the 'good-life' as a continuity in the history of Central Africa. Defined broadly as the fertility of women, successful hunt, abundant harvest, material wealth and prosperity, to become a like a European, to replace Europeans, salvation, protection against evil, sorcery and witchcraft, the authors demonstrate how the urge to 'prevent misfortune and maximise good fortune' has been manifested in a cycle of religious renewal stretching back several centuries within the region. ${ }^{66}$

In many respects the Luba Christian movement represented the latest stage in that trajectory of religious renewal. Christian missionaries and their African agents were received as the newest guarantors of personal security. Both African testimony and mission sources stress that what first drew the crowds to Mwanza was not preaching but the demonstration of the power of the Holy Spirit though divine healing. CEM historian, David Garrard describes how Burton prayed for a man named Tentami who had been bent over double with back pain for years. There was an audible crack and

\footnotetext{
${ }^{65}$ P. Conrad. 'La Mission de Kulu', Le Messenger du Saint Esprit, May 1913, 281.

${ }^{66}$ W. De Craemer, W, Fox, R. \& J. Vansina, 'Religious Movements in Central Africa: A Theoretical Study', Comparative Studies in Society and History. 18, 4 (1976), 458-75
} 
the man stood bolt upright: 'As a result many followed closely to see what else would happen. They wondered if they would also eventually possess the same power'. ${ }^{67}$

The Pentecostal missionaries of the CEM were responsible for many other healings, which were diligently recorded in the $C E M R$ with great regularity. In an era when disease, pestilence and malnutrition were pervasive and biomedicine was far from efficacious, divine healing had great appeal and increased the number of converts. ${ }^{68}$ In 1921 the CEM experienced a revival that Burton described as 'The Luban Pentecost'. Henceforth the gifts of the Holy Spirit - divine healing, glossolalia, prophecy and exorcism -- became available to all those baptised in the Holy Spirit, adding to the movement's effect. ${ }^{69}$ Such was the appeal of the CEM's pneumatic practice that it spread to the Plymouth Brethren. ${ }^{70}$ Burton's powers appeared to extend well beyond healing. In the first months the mission at Mwanza he undermined a local traditional healer through his success in the hunt. His ability to provide sustenance for his evangelists convinced many local villagers of the veracity of Christianity, and on one occasion his provision of a hunted buffalo for a hungry village prompted fifty converts. ${ }^{71}$ The CEM's prolific hunter-turned-evangelist,

\footnotetext{
${ }^{67}$ Garrard, Zaire Evangelistic Mission, 70, 418.

${ }^{68}$ W. Kalusa, Disease and the Making of Missionary Medicine in Colonial Northwestern Zambia: A Case of Mwinilunga District, 1902-1964, unpubl. PhD diss, Johns Hopkins University, 2003. CAM, Burton to Salter, 1 November 1925.

${ }^{69}$ Burton, God working, 77-83.

${ }^{70}$ Burton, God Working, 57-8

${ }^{71}$ Burton, God Changes a Man, 58-60; Moorhead, Missionary Pioneering, 48-49.
} 
Mudishi, also won converts through his ability to protect villagers from predators, as well as through his preaching and healing. ${ }^{72}$

Although Protestant missionaries tended to demean traditional prophets as frenzied and demonic it is clear that the Luba viewed Burton as a prophet standing in the indigenous tradition. On introducing carpentry in the mission workshops, he was referred to as the 'Father of Bwanga' a broad term associated with medical-magical substances intended to increase a person's ability to act in the world. Missionaries often failed to grasp the ontological continuities integral to their success. Burton's ability to fix a gun or heal was often not attributed to God but powers ascribed to Bwanga. ${ }^{73}$ In a remarkable account of how African traditional healers attempted to incorporate the power of Europeans, one missionary couple described how a charm filled with powerful ingredients was given the name of a missionary, placed on a chair and paid homage. ${ }^{74}$ On other occasions the slow cultural shift towards Christian notions meant that prayer was referred to as a new charm efficacious for hunting and fishing. ${ }^{75}$

Even acts of iconoclasm can be interpreted as in term of cultural continuity. From the outset of the encounter, missionary accounts stressed the spontaneity with which

\footnotetext{
${ }^{72}$ Burton, Mudishi, 174, 178. Burton, Luba religion, 115

${ }^{73}$ Anon. 'Bwanga', CEMR 8, (1925), 87-88. P. Tempels, Bantu Philosophy. Paris, 1953 (1945), 23, $31,46,59$.

${ }^{74}$ S. \& F. D. Johnstone, 'Kipushia', CEMR 15, (1927), 184-86; W.F.P. Burton, 'The Secret Societies of Lubaland', Congo Belge', Bantu Studies, 4, 1, (1930), 246-7.

${ }^{75}$ Burton, Mudishi, 174, 178. Burton, Luba religion, 115
} 
converts came forward to publically burn their charms on huge village bonfires. ${ }^{76}$ In this way, the Luba Christian movement took on the appearance of a 'witchcraft' eradication movement, standing in a Central African tradition of cyclical renewal. Missionaries and their African accomplices were the new prophets who provided blessing and healing and rid society of witchcraft and sorcery when its social costs became too high. They stood in a tradition of rupture.

Ageing, revival and reprise

Rarely did the African Church progress in the manner desired by missionaries. There were systemic tensions between missionaries and their nascent churches and these soon manifested themselves in Katanga. The first set of tensions was caused by ageing and bureaucratisation. In the pioneering stage of African Christianity, evangelists had autonomy from overstretched and linguistically challenged missionaries. Struggles commenced with the second generation of missionaries who sought to limit the speech and regulate the actions of African pioneers in the name of orthodoxy. Racism and paternalism intensified the conflict as missionaries refused to give these church founders the respect they deserved. At times, affronted African Christians fatigued by being patronised broke away to form prophetic movements, independent of missionaries. The first signs of this process were evident amongst a handful of freed slaves who were some of the first Christians to proselytise the region. In the case of American Methodism, missionaries who found them 'uppity' marginalised ex-slaves. Three former slaves-cum-evangelists also left the Pentecostal CEM to join Watch Tower, which in its early Congolese manifestation was a black-

\footnotetext{
${ }^{76}$ Salter, $R W 10$ (1917); Burton, $R W, 11$ (1917).
} 
led anti-colonial movement. ${ }^{77}$ Moreover, the first generation of evangelists aged. By the late 1920s Burton was complaining that their zeal had been replaced by a concern with status and remuneration. ${ }^{78}$ The young men who had founded the movement had become elders, and in the process, repressive of their juniors. They began to reproduce patterns of gerontocracy present in wider society, dampening their earlier egalitarian tendencies. By the 1930s the next generation were ready for alternatives to church such as neo-traditional secret societies or they sought revival in the existing churches of which they were part.

There were also external motors of change acting on the Luba Christian movement. The CEM, and similar evangelical Protestant movements, were under constant surveillance from a nervous colonial state, which had witnessed the Chilembwe Uprising of 1915 in Nyasaland and Kimbanguism in its own territory in 1921. The Belgians blamed 'Protestant sects' for inspiring such movements, and in order to keep the peace Burton sought to restrain some of his more zealous African workers. ${ }^{79}$ But when missionaries failed to be culturally sensitive African Church prophets arrived at more satisfying syntheses of old and new. Prophetic movements established continuities with food taboos, models of leadership, and most importantly, in the domain of healing. In an attempt to meet Africans' enduring concern for health and personal security, the prophets chose to elevate Christ's healing ministry over his sacrifice. Kimbangu was Congo's most celebrated example of such a prophet but

\footnotetext{
77 Maxwell, 'Freed Slaves'.

${ }^{78}$ CAM, Burton to Salter, 13 November 1929.

${ }^{79}$ D. Maxwell, 'The Soul of the Luba: W.F.P. Burton, Missionary Ethnography and Belgian

Colonial Science', History and Anthropology 19, 4 (2008), 325-351.
} 
within the CEM there were numerous young men who, empowered by the Holy Spirit, wanted to act beyond the bounds of what missionaries considered orthodox Christianity: to give themselves titles such as 'mediator', or 'powerful'; to accuse others of witchcraft; to gather the sick together at healing centres; to prophesy what was not in accord with scriptures. ${ }^{80}$

Socio-economic change within Katanga also frustrated the CEM's plans to expand and consolidate. Young men were increasingly drawn into migrant labour. Villages emptied of young people leaving missionaries only with the elderly and children to proselytise. Rural labour became difficult to procure for mission workshops and as carriers on treks. Many of the most committed Christians forsook the opportunity to work as evangelists for better-paid employment in the growing industrial sectors of Katanga. In 1928 Burton bemoaned the fact that the use of Bwanga had returned to villages where converts had burnt it nine years earlier. He lacked the evangelists to establish churches in these villages and the former ways had 'crept back' ${ }^{81}$ Once in towns and on mining compounds young men escaped missionary supervision, often founding their own welfare or customary associations. And when they returned home their former deference to the white missionary and his religion had vanished. Indeed, though the Luba Christian movement undercut the existence of some socalled secret societies (associations) -- Maleka, Bantambo, Katyoma -- these were

\footnotetext{
${ }^{80}$ While Burton was maintained strict control over his evangelists, missionary colleagues on other stations were less able or willing. Eventually 'Rules' had to be pinned to the wall of every CEM church to limit contain unorthodox behaviour. See 1951 Copy, in Garrard, 'Zaire Evangelistic Mission', Fn 25, 222-223.

${ }^{81}$ CAM. Burton to Salter 28 June 1928.
} 
replaced by Mpungu, Tambwe-bwanga and Kasongo, while the Budye Association continued throughout the colonial period into the post-colonial era. ${ }^{82}$

There were subsequent Christian revivals in the 1930s and 1950s and each infused Luba Christianity with greater local depth. The first in the 1930s coincided with the Great Depression and the return of unemployed young men. It was also marked by the arrival of a Gestetener Duplicator, which enabled the widespread dissemination of Luba Scriptures and primers. There was a passion for Luba scriptures, particularly those referring to the Second Coming of Christ. The greater availability of the scriptures and teaching material brought about a greater uniformity of belief within the CEM work. The 1950s revival was marked by new kinds of song: a move from translated hymns to locally composed choruses. Neither of these two subsequent revivals had the vigour or made such profound breaks with traditional heritage as did the first generation of Christians. While traditional sacred objects and witchcraft continued to be publically burnt, believers stood at a distance, Bibles in hand, fearing that the spirits would jump out and re-enter them. ${ }^{83}$ In spite of the work of disenchantment by missionaries and African Christians, fear of evil spirits and socalled idols did not abate. As Birgit Meyer has observed such things were 'now conceived as belonging to the realm of Satan and his powers of darkness', and continued to haunt 'African versions of Christianity'. ${ }^{84}$

\footnotetext{
${ }^{82}$ Editor, 'Heathenism in 1952...' CEMR, 191 (1952) 2329-31

${ }^{83}$ Interviews conducted by David Maxwell with Edmund and Heather Rowlands, Margate, England 15 March 2006 \& David Womersley, Rushdon, Northants, England, 27 September 2006 \& 29 January 2008.

${ }^{84}$ Meyer, 'Religious Revelation', 438.
} 


\section{Conclusion: Towards a Synthesis of Old and New}

Elements of this account are present in the work of Vansina and his colleagues but here they are given a different emphasis. While the Luba Christian movement fits into De Creamer, Fox and Vansina's trajectory of periodic societal cleansing, this article does not share their notion of a `common Central African culture ... [of] rituals, symbols and beliefs' 'reshuffled' for each new wave of enthusiasm. ${ }^{85}$ The Luba religious system was both dynamic and open to new ideas and practices, becoming more plural throughout the twentieth century. Although the process of societal cleansing was cyclical it was also unidirectional and the means of renewal was increasingly Christian. Where once traditional Luba prophets carried out the destruction of charms and other magical substances, missionaries, evangelists and independent church prophets performed it from the 1920s onwards. And Christians engaged in cleansing rather than old style eradication, dealing with a multitude of individual cases rather than a communally administered cure. Thus the new Christian practice of witchcraft cleansing undercut the possibility of old style witchcraft eradication movements. Drawing from his extensive knowledge of the encounter of Christianity with the Kuba in western Congo, Vansina observes that by the eve of the new millennium Pentecostal churches had absorbed 'all aspects' of rituals providing personal security. ${ }^{86}$ Amongst the Luba of Katanga where Pentecostal missionaries arrived in 1915 this process began eight decades earlier.

\footnotetext{
${ }^{85}$ De Craemer, 'Religious Movements', 472-73.

${ }^{86}$ Vansina, Being Colonised, 269.
} 
Moreover, this account ascribes more importance to the originality, exclusivity and social significance of Christian ideas. Though Christianity continued to address the enduring search for the good life it was not absorbed into an unchanged cosmology, a system of thought that remained African and traditional. Instead, through the gifts of the Holy Spirit, ideas of salvation, the sacraments, liturgy, discipline and literacy, Christianity possessed sources of strength, which enabled it to innovate. ${ }^{87}$ Bornagain conversion and associated practices of baptism, divine healing, exorcism and iconoclasm could inaugurate immediate ruptures with society and culture. But some of these could be ephemeral and in times of crisis believers might turn to traditional or neo-traditional associations and possession cults for personal security. Other phenomena associated with Christianity such as new temporalities and reading practices could have a post conversion effect, exerting a cumulative impact that in time made a Christian worldview appear natural and local.

${ }^{87}$ Gray, Black Christians, white missionaries, New Haven 1990, 50. 
Abstract:

This article studies the Christian movement that occurred amongst the Luba of Katanga, Belgian Congo c.1915 -1950, paying particular attention to how it was received by different social categories and mediated by local religious enthusiasts. The notion of conversion is examined across two generations with reference to ageing, revival and reprise via a case study of the Congo Evangelistic Mission (CEM), a Pentecostal faith body. The paper shows how the CEM's literary and pneumatic practices were understood both in terms of ruptures with what had gone before and through establishing continuities with pre-existing culture, particularly the search for social harmony. 